Indonesian Journal of Nutrition and Dietetics Vol. 6, No. 2, 2018: 58-63
Available online at: http://ejournal.almaata.ac.id/index.php/IJND DOI : http://dx.doi.org/10.21927/ijnd.2018.6(2).58-63

\title{
Nutrition status as dominant factors related to the age of menarche in teenagers
}

\author{
Wahyuningsih, Nimas Arum Septyaningtyas \\ Department of Nursing, Faculty of Health Sciences, Universitas Alma Ata, Jalan Brawijaya No.99 \\ Tamantirto Yogyakarta, Indonesia 55183 \\ *corresponding author: wahyuningsih.psik.aa@gmail.com
}

\begin{abstract}
ABSTRAK
Latar belakang: Menarche adalah periode menstruasi pertama pada seseorang yang terjadi sekitar usia 11-13 tahun. Rata-rata usia menarche kini menurun mendekati usia normal. Hal ini disebabkan oleh beberapa faktor seperti, menarche ibu, aktivitas olahraga, paparan media massa dewasa, status gizi, dan pendapatan orang tua. Ini akan berdampak pada kehidupan selanjutnya.

Tujuan: Untuk mengetahui faktor-faktor dominan yang berhubungan dengan usia menarche pada remaja putri di SMPN 01 Jumapolo Kabupaten Karanganyar tahun 2016.

Metode: Jenis penelitian yang digunakan adalah metode penelitian kuantitatif dengan pendekatan cross sectional, dengan 97 remaja putri sebagai sampel menggunakan teknik total sampling. Data dikumpulkan menggunakan kuesioner dan dianalisis menggunakan uji korelasi rank spearman dan uji regresi linier.

Hasil: Penelitian ini menunjukkan bahwa ada hubungan antara usia menarche remaja putri dan status gizi (BMI) ( $p$-value 0,032) dan usia menarche remaja putri dan dengan pendapatan orang tua ( $p$-value 0,018). Usia menarche ibu, kebiasaan olahraga dan frekuensi menonton program favorit tidak memiliki hubungan dengan usia menarche remaja perempuan. Analisis multivariat menunjukkan bahwa faktor status gizi (BMI) merupakan faktor yang paling dominan terkait dengan kekuatan hubungan (B) -0,94.

Kesimpulan: Status gizi merupakan faktor yang paling dominan yang terkait dengan usia menarke, oleh karena itu diharapkan dapat memberikan pendidikan kesehatan bagi remaja putri untuk meningkatkan gizi pada rentang usia 9-13 tahun.
\end{abstract}

Kata Kunci: Usia menarche, status nutrisi, remaja

\begin{abstract}
Background: Menarche is the first period of menstruation in a person occuring around the age of 11-13 years. The average age of menarche is now decreasing approaching normal age. This is due to several factors such as, maternal menarche, sports activity, adult mass media exposure, nutritional status, and parent income. This will have an impact on the next life.

Aim:To determine the dominant factors associated with the age of menarche in female teenager in SMPN 01 JumapoloKaranganyarRegency in 2016.

Methods: The type of research used was quantitative study method with cross sectional approach, with 97 female teenagers as samples using total sampling technique.Data were collected using questionnaire and analyzed using Spearman rank correlation test and linear regression test.

Results:This research showed that there is a relationship between age of menarche of female teenagers and nutritional status (BMI) ( $p$-value 0.032) and age of menarche of female teenagers and with parent income ( $p$-value 0,018). The age of maternal menarche, exercise habits and frequency of favourite programme watching has no relationship with the age of menarche of female teenagers. Multivariate analysis showed that nutritional status factor (BMI) was the most dominant factor related to strength of relationship (B) -0.94 .

Conclusion: Nutrition status is the most dominant factor associated with age of menarche, therefore, it is expected to provide health education for female teenagers on to improve nutrition in the 9-13 year of age range.
\end{abstract}

KEYWORDS: age of menarche, nutritional status, , teenagers 


\section{INTRODUCTION}

Puberty in teenagers shows changes in secondary sexual signs to sexual maturity (1). The age limit of teenagers by the World Health Organization (WHO) is 10-19 years old (2), while in Indonesia the age of teenagers is 10-24 years old (3). Female teenagers experience the first menstrual period (menarche) at the age of 11-13 years (1). This menarche is one of the signs of female teenagers experiencing puberty, a period in which sexual maturity is formed (4).

In Indonesia, the result of basic health research (Riskesdas) shows that the average age of menarche in Indonesia is now 13 years. This data shows the average age of menarche approaching normal age. This is due to the better nutrition and health. However, the risk of first menstruation at an earlier age (early menarche) may occur (4).

Early menarche can occur in children younger than 10 years old. Based on the results of Riskesdas age of menarche in 6-8 years old has occurred in a small $(<0,5 \%)$ group of children in 17 provinces. Indonesia itself ranks $15^{\text {th }}$ out of 67 countries with the decline of age of menarche reaching 0.14 years per decade (5). Riskesdas got data showing thatdecline of age of menarche is less than 9 years old and menarche is getting slow to 20 years (5).

Early and late menarche age can provide various effects for teenagers such as increasing the risk of breast cancer, cervical cancer and uterine myoma (4). Other studies also suggested that age of menarche under 12 years old is associated with risk of breast cancer, abdominal obesity, insulin resistance, fat accumulation in adipose tissue, cardiovascular disease risk and hypertension (6).

Late menarche can lead to failure of mineral accumulation in bone and decrease bone mineral density (7). Previous studies have mentioned that 12 (16.2\%) subjects got first menstruation at the age of more than 15 years and 8 of them had decreasing bone density (8), besides it can also determine the risk factors for osteoporosis and fractures in women (9).Age of menarche is influenced by two factors, first, endogen factor, which is genetic and exogenous factor like family social economic status, nutrition status, residence, physical activity (sport) and exposure to mass media (4).

A preliminary study conducted on February 6 , 2016 at SMPN 01 Jumapolofound that from 6 female students encountered, they experienced age of menarche at 10,11, 12 and 13 years old. Based on the description above, SMPN 01 Jumapolo has the highest number of students in Jumapolodistrict. This school is located in the village area with diverse backgrounds of students, so it is necessary to do research to know the factors associated with age of menarche in female teenagers of SMPN Jumapolo 01.

\section{MATERIALS AND METHODS}

This research type was quantitative study method, with cross sectional study design. The research location was at SMPN 01 Jumapolo, Karanganyar Regency which was conducted in April 2016. The sample was 97 female teenagers. Before the research was carried out, the ethics committee reviewed the UAA ethics committee first.

This research used total sampling technique. The inclusion criteria are the seventh grade female teenagers who have had menstruation while in grade VII or in elementary school and are willing to be the respondent, while the exclusion criteria are female teenagers who are absent during research and those who do not know the age of mother's menarche.

The variables in this research were independent variables, which are factors related to of menarche including nutritional status, maternal menarche (genetic age), socioeconomic status, adult mass media exposure and sports activity while the dependent variable was menarche age of female teenagers. Nutritional status is condition of nutrition fulfillment of teenagers seen from BMl; maternal menarche is the first time the mother experiences menstruation; sosiaoeconomic status is monthly income of parents; adult mass media exposure is the frequency of teenagers in accessing the adult mass media; sport activity is frequency of teenagers in exercising. The instruments used in this research were questionnaire amounting to 10 items of questions, scales, microtoise, bolpoint, paper, camera, and note book. 
The data analysis used was bivariate analysis to see the relationship between dependent variable and independent variable using Rank Spearman correlation test while multivariate analysis is intended to know the most dominant factor related to menarche age using multiple linear regression test.

\section{RESULT}

\section{Univariate}

Description of Menarche age, nutritional status of young women, age of maternal menarche, socio-economic, mass exposure of adult media, sports activities for young women can be seen in the table 1.

Based on the results of the analysis, it was found that the average age of young menarche was at the age of 12 years, the average nutritional status of girls was 17.97 (thin category), the age of women teenage menarche was 13 years, the average income of parents is Rp. 1,600,000, the frequency of watching media for adults is 22 times a month, the average exercise is 2 times a week.

\section{Analisis Bivariate}

The following is a table of the results of the bivariate analysis of independent variables and the dependent variable of the study.
1. The Relationship between the Nutritional Status and Age of Menarche in Female Teenagers This research was conducted on 97 girls at SMPN 01 Jumapolo Karanganyar Regency. The results showed that the average nutritional status of female teenagers was 17.97 . There is significant correlation with the $p$-value value of $0.032(p<0.05)$.

2. Relationship between Sports Activity and Age of Menarche in Female Teenagers

The results can be seen from table 2 , that there is no significant correlation between age of menarche age of female teenagers and sport activity with $p$-value of 0.359 ( $p>0,05)$.

3. The Relationship between Adults' Mass Media Exposure and Age of Menarche in Female Teenagers

Based on the results of the research and as outlined in table 2, there was no significant correlation between the age of menarche of female teenagersand adult's mass media exposure with $p$-value of $0.592(p>0,05)$.

4. Relationship Between Age of Maternal Menarche and Age of Menarche in Female Teenagers The results, as can be seen in table 2, show that there is no significant relationship between age of menarche in female teenagers and age of maternal menarche with $p$-value of $0.977(p>$ 0.05).

Table 1. Distribution of research variables for female adolescents in Class VII at Jumapolo 01 Junior High School

\begin{tabular}{ccccc}
\hline Variabel & Minimum & Maksimum & Mean & Standar Deviasi \\
\hline Age of menarche & 9 & 13 & 12,05 & 0,727 \\
Nutrition status (IMT) & 12,7 & 27,23 & 17,97 & 2,7 \\
Age of Maternal Menarche & 10 & 17 & 13,48 & 1,33 \\
Parent Income & 10000 & 18000000 & 1624072,16 & 1992355,224 \\
Watching frequency & 3 & 30 & 22,00 & 10,524 \\
Sprots Activity & 1 & 3 & 1,66 & 0,675 \\
\hline
\end{tabular}

Table 2. Results of Bivariate Analysis in Female Teenagers of Grade VII at SMPN 01 Jumapolo April $2016(\mathrm{~N}=97)$

\begin{tabular}{ccc}
\hline Variables & Correlation Coeficient & p-value \\
\hline Nutritional status (IMT) & -0.218 & 0.032 \\
Sports Activity & -0.04 & \\
Watching frequency & 0.055 & 0.592 \\
Age of Maternal Menarche & -0.003 & 0.977 \\
Parent Income & -0.24 & 0.018 \\
\hline
\end{tabular}


Table 3. Results of Multivariate Analysis in Female Teenagersof Grade VII at SMPN 01 Jumapolo April 2016 ( $N=97)$

\begin{tabular}{ccccc}
\hline Step & Variables & Coefficient & $\begin{array}{c}\text { Correlation } \\
\text { coefficient }\end{array}$ & p-value \\
\hline Step 1 & BMI & $-0,91$ & $-0,337$ & $<0,001$ \\
& Income & $-2,988$ & $-0,082$ & 0,403 \\
& Constants & 13,727 & & $<0,001$ \\
Step 2 & BMI & $-0,94$ & 0,35 & $<0,001$ \\
& Constants & 13,739 & & $<0,001$ \\
\hline
\end{tabular}

5. Relationship between Parent Income and Age of Menarche in Female Teenagers

The results of the research can be seen in table 2 that there is a significant relationship between the age of menarche in female teenagers and parent income with $p$-value of $0.018(p<0.05)$.

\section{Analisis Multivariate}

Based on Table 3, two multivariate analyzed factors using a linear regression test resulted in BMI was the most dominant factor associated with age of menarche in female teenagers compared to other factors with relationship strength (B) -0.94 .

\section{DISCUSSION}

Nutritional status has a relationship with age of menarche because the intake of food consumed can influence growth. Physical growth includes one of the influencesfrom the intake a person consumeswhich will cause sexual growth. The results of this research are in accordance with the research from Karis about age of menarche and nutritional status of female teenagers getting a significant result with $p$-value of 0.025 (10). The results of this research differ from that of Afrian in terms of menarche factors that have an average BMI of $40,58 \mathrm{~kg}$ which can be classified in the category of obesity (11). Based on research from Linda S.A, it shows that overweight conditions can influence the early age of menarche in a certain race or class (12). Nutritional status seen from BMI can influence sexual maturity in teenagers. Early maturity of sexuality will have a higher BMI than those whose sexual maturity is delayed at the same age (1).

Physical activity has no relationship to the age of menarche as most female teenagers exercise only during school hours, so respondents rarely exercise outside school hours. This result is similar to Nur's research on physical activity with age of menarche. The result obtained is that there is no correlation between age of menarche and sport activity with $p$-value value 0.225 (13). Physical activity is one of the factors associated with the occurrence of menarche in female teenagers. Excessive activity, for example, more than 3 times a week with duration of more than 20 minutes may interfere with hormonal activity leading to a decrease in progesterone production and this can delay endometrial maturity (4). The results can be different from theories because of the lack of awareness female teenagers in the importance of doing normal exercise on a weekly basis.

The results can be different from theories due to the lack of openness of the respondents, thus providing unsuitable results in the analysis. This research used questionnaire technique. Digging the openness of the respondents cannot only be done using questionnaires but also can be done with direct interviews to get more appropriate results. This is in contrast to Fajrriyanti's research on the age of menarche of female teenagersand adult's media exposure which received p-value of 0.000 (14). Watching adult media over 3 hours can interfere with sexual maturity of the female teenagers. This is the result of stimuli seen that will influence the production of the melatoninhormone that plays a role in the release of $\mathrm{GnRH}$ hormone (4).

The results of this study is similar to Karis's research on the age of menarche in female teenagers and age of maternal menarche with the p-value of 0.459 (10), which means no relationship. The age of maternal menarche is a factor in the occurrence of the first menstrual period in female 
teenagers because it is associated with inherited estrogen. Genetics can predict the age of menarche from their female descent. The theory suggests that the menarche age of siblings or twin siblings is more influential on the predicted age of menarche (15). The results can be different from theories because there are some female teenagers who claimed that their mother forgot exactly when they had menarche. They do not think it's important to remember or record the age of menarche.In addition, this can be different because of diet between parents and female teenage, such as junk food.

Parent income is one of the factors associated with the occurrence of menarche. Parent income is associated with family purchasing power.If income is high, the purchasing power of the family will be better, and vice versa, if the income is low, the purchasing power of the family is limited.Rochma's research on income shows that the menarche age of children of high socioeconomic age gets menarche younger than children from low socioeconomic levels (16).

Age of menarche is one of the signs that a person already experiences puberty or someone is ready to reproduce. Menarche is common in young women aged 11-13 years.Matters associated with the age of menarche are divided from exogenous and endogenous factors. One of the exogenous factors associated with age of menarche is the nutritional status that can be seen from female teenagers' BMI.

\section{CONCLUSION AND RECOMMENDATION}

Characteristics of respondents in this research are that they are at the age of early adolescence which is the 11-14 years old with female respondents and have experienced menstruation. Many respondents get menarche in the normal category with nutritional status in the skinny category, late age of maternal age, insufficient parent income, frequent exposure to adult category media and rare category in sports activities. Factors of nutritional status and parent income are factors associated with the age of menarche of female teenagers in SMPN 01 JumapoloKaranganyar Regency. Nutritional status is the most dominant factor related to age of menarche age in female teenagers of grade $\mathrm{VII}$ at SMPN 01 JumapoloKaranganyar Regency.

Based on the above conclusions, the suggestions that can be given for action are as follows: (1) Health workers: It is expected that health workers, especially the health department can provide counseling in schools to increase the knowledge of female teenagers about reproduction so that teens are better prepared when facing menarche; (2) For Research Site (SMPN01 Jumapolo): It is expected that junior high school can establish cooperation with health workers in providing health education to educate sex or reproduction to students to help the readiness in health after having menarche in the future; (3) For Further Research: It is expected that further research can examine other factors on the variables associated with age of menarche, so that other factors related are found.

\section{REFERENCES}

1. Desmita. Psikologi Perkembangan. Bandung: PT Remaja Rosdakarya: 2008

2. Kusmiran, Eny. Kesehatan Reproduksi Remaja dan Wanita. Jakarta: Salemba Medika:2011.

3. BKKBN. Kajian Profil Penduduk Remaja (10-24Tahun). Pusat Penelitian dan Pengembangan Kependudukan. Jakarta: BKKBN Provinsi. Seri INo.6/Pusdu- BKKBN/ Desember2011.

4. Proverawati, Atikah dan Misaroh. Menarche Menstruasi Pertama Penuh Makna. Yogyakarta: Nuha Medika: 2009.

5. Riset Kesehatan Dasar. Jakarta: Badan Penelitian dan Pengembangan Kesehatan, Departemen Kesehatan, Republik Indonesia: 2010.

6. Karapanou,Odan Papadimitriou, A. Determinants of Menarche. BioMedCentral:2010:8-115.

7. Rogoletal.Growth And Pubertal Development In Children And Adolescents: Effects Of Diet And Physical Activity. Ameican Journal of Clinical Nutrition: AmJ Clin Nutr; 72(suppl):521S-8S. 2000.

8. Maspaitella,MeidiLandDieny, FillahFithra. Hubungan Asupan Kalsium Dan Fosfor, 
Indeks Massa Tubuh, Persen Lemak Tubuh, Kebiasaan Olahraga, Usia Awal Menstruasi Dengan Kepadatan Tulang Pada Remaja Putri. [Undergraduate thesis] Diponegoro University:2012.

9. RanS,PeiY-F,LiuY-J,ZhangL, HanY-Y,etal. Bivariate Genome- WideAssociation Analyses Identified Geneswith Pleiotropic Effects for Femoral Neck Bone Geometry and Ageat Menarche. PLoSONE 2013:8(4):e60362.

10. Delina, Karis Amalina. Faktor- Faktor Yang Berhubungan Dengan Usia Menarche Pada Remaja Putri di SMPN 155 Jakarta Tahun 2011. [Skripsi]. Jakarta:UINSyarifHidayatullah: 2011.

11. Afrian, Yanti Siswantini. Hubungan Berat Badan, Persen Lemak Tubuh, Status Gizi(IMT)/ U,Umur Menarche Ibu Dengan Umur Menarche Pada Siswi Di SDN Cikaret 01 Cibinong Kabupaten Bogor Tahun2012. [Skripsi]. UniversitasIndonesia: Depok:2012.
12. Linda SA,PennyGL. Maturational Timing And Overweight Prevalence In US Adolescent Girls. American Journal ofPublic Health. 91(4):642-644. Am JPublichealth.2012.

13. Fitriyah, Nur. Faktor-Faktor Yang Mempengaruhi Menarche Pada Siswi SMP Muhammadiyah 3 Yogyakarta. [NaskahPublikasi]. Yogyakarta: Stikes Aisyiyah: 2015.

14. Fajriyanti, LA. Hubungan Antara Status Gizi, Kontak Media Pornografi dengan Menarche Dini. [Skripsi] UniversitasAirlangga. Surabaya:2008.

15. F.R. Tehrani, P.Mirmiran, S. Zahedi-Aslet,al. Menarcheal age ofmothersand daughters: Tehran Lipidand Glucose Study. EasternMediterranean HealthJournal. Vol.16No. 4:2010.

16. Rochma,KM. Hubungan Media Informasi Dan Status Ekonomi Keluarga Dengan Kejadian Menarche Pada Remaja Siswi Di SMP Negri 2 Tungkal Jaya Kabupaten Musi Banyuasin Tahun 2013. Poltekes Kemenkes Palembang: 2013 